\title{
Need Assesment SDM Ekonomi Islam
}

\author{
Oleh: Syafrudin Arif M. M.*
}

\begin{abstract}
Islam economically provides its great expositions on the quality of human resource. Islam stimulates the human being to be progressive and successful on the whole aspects of their life, including in the economic ones. The success in this world as well as the next world is one of its progressive economic prescriptions. But becouse of the great extant economic underdeveopment over the Muslim world or areas nowadays, as if it is forgotten. This paper, thus, represents the treatment of the Islamic teaching especially on the enpowerment of human resource in terms of the economic fields and of how to accomplish the economic underdevelopment problems in the perspective of Islam. There are a lot of verses of the Holy Koran, the Prophetic Traditions, and his great companions to assert it. In a fact, human being is one of the driving factors of economic development. In a fact, Islam historically overcome the problems based on the comprehensive ways involving both a system and an individual, or the voluntary method, the compulsory method, and the method of the state's responsibility. In the context of the contemporary islamic economics, the pioner human resources are indispensable to achieve.
\end{abstract}

Keywords: SDM, ekonomi Islam, sukses di dunia dan akhirat

\section{Pendahuluan}

Islam tidak menyerukan hidup miskin untuk mencapai kebahagiaan akhirat atau untuk mendapatkan surga. Baik terhadap orang-orang miskin Islam.

"Penulis adalah dosen tetap STIES Bengkalis dan peneliti dalam bidang ekonomi 
maupun orang-orang kaya, Islam memberikan pencerahan dan penyelesaian secara menyeluruh, terutama dengan cara membangun kepribadian manusia yang dinamis dan tangguh dalam menghadapi setiap persoalan hidup. Karena sebenarnya kemiskinan dan kekayaan (kecukupan), keduanya sama-sama bisa menimbulkan keburukan dan mendorong manusia kepada kejahatan. Dengan mendudukkan manusia sebagai khalifah (pemimpin ataupun wakil Tuhan) di muka bumi, Allah Swt dalam al-Qur'an memandang manusia sangat luhur dan mulia sehingga dia layak mengemban tugas itu daripada ciptaan Allah yang lainnya. ${ }^{1}$ Juga berdasarkan data sejarah, Nabi Muhammad Saw telah berhasil memberikan contoh yang sempurna mengenai cara pengentasan kemiskinan dan keterpurukan ekonomi yang melemahkan manusia. Metode dan tindakan itu dilakukannya dengan menggunakan metode menyeluruh sebagaimana diajarkan oleh Allah Swt di dalam al-Qur'an. Penyelesaian yang dicontohkannya tidak sebatas melalui perspektif ekonomi saja sebagaimana yang telah diketahui pada umumnya seperti sarana zakat, shadaqah, infaq, waqaf, hadiah, dan hibah, akan tetapi lebih dari itu.

Lebih jauh, tulisan ini akan mengupas mengenai urgensitas peningkatan kualitas SDM Ekonomi Islam saat ini yang sangat berguna bagi pertumbuhan ekonomi baik secara mikro maupun makro tetapi tidak secara khusus berbicara terkait dengan peranan lembaga keuangan Islam sekarang ini, seperti Bank Syari'ah, BMT, dan Asuransi Syari'ah. Jelasnya, tulisan ini menunjukkan bahwa penguatan SDM secara perseorangan berdasarkan paradigma Islam yang khas tentang manusia sangat menentukan bagi keberhasilan program-program ekonomi Islam secara kelembagaan juga. Karena keberhasilan suatu lembaga pada dasarnya adalah buah dari gabungan keberhasilan-keberhasilan perorangan di dalamnya. Semua itu sangat penting untuk dibicarakan mengingat sebagian besar penduduk miskin di Indonesia adalah orang Islam.

Untuk mengungkapkan kebenaran ajaran Islam dan kekayaan peradabannya, akan dipaparkan juga di sini wawasan dan contoh Nabi Muhammad Saw serta sahabatnya sehubungan dengan hal itu secara jelas. Kendati demikian, pembahasannya tetap tidak mengesampingkan kenyataan sumber daya manusia dalam perspektif ekonomi umum di Indonesia, karena hal itu merupakan dasar realitas yang membentuk pengalaman dan pengetahuan kita mengenai arti pentingnya penumbuhan SDM Ekonomi Islam di Indonesia.

\section{Persoalan Sumber Daya Manusia dan Umat Islam di Indonesia}

Adam Smith dalam Wealth of Nations menegaskan bahwa pengembangan negara sangat ditentukan oleh penguasaan ketrampilan (skill), kecakapan

${ }^{1}$ QS. Al-Baqarah: 30. 
(dexterity), dan penilaian (judgment). ${ }^{2}$ Menurut Harlison, dia menjelaskan bahwa human resources adalah kekayaan bangsa (wealth of nations) yang terpenting. Karena itu, tujuan pembangunan (development) yang tepat adalah pemberdayaan manusia dengan cara yang terbaik yang ditujukan untuk kegiatan produktivitas yang berupa pengembangan keterampilan, pengetahuan, dan kapasitas kekuatan buruh. ${ }^{3}$ Sedangkan yang lainnya seperti pertumbuhan ekonomi (economic growth), tingkat kesejahteraan yang lebih tinggi, dan penyebaran pendapatan yang lebih adil, itu semua sebenarnya merupakan dampak lebih lanjut dari keberhasilan pemberdayaan manusia. ${ }^{4}$ Menurut Harlison dan Mayers model, sumber daya alam (SDA), bantuan dan pandangan luar negeri jelas memainkan peranan penting dalam pertumbuhan ekonomi namun tidak ada yang lebih penting daripada SDM. ${ }^{5}$ Lebarnya jurang pemisah antara tingkat pendapatan negara industri dan negara berkembang antara lain adalah akibat perbedaan mutu SDM negara-negara yang bersangkutan.

Bagi negara berkembang, peluang untuk mengejar ketertinggalan kualitas SDM yang unggul dalam tingkat produktivitas dibanding negara maju bukanlah sesuatu yang mustahil. Karena mutu SDM bukanlah sesuatu yang dibawa sejak lahir, melainkan kemampuan yang diperoleh kemudian sehingga SDM bisa ditingkatkan dan diperbaiki. Terlebih berdasarkan fakta dan pengalaman sejarah, banyak prestasi telah diukir oleh baik penduduk Indonesia secara perorangan maupun kelembagaan, sebagai contoh pelajar Indonesia telah menjadi juara olimpiade fisika antar negara.

Selanjutnya, dasar untuk menganalisis kualitas SDM bisa dikelompokkan menjadi dua komponen: ${ }^{6}$ (1) komponen masukan (input) dan (2) komponen luaran (output). Dalam kerangka komponen masukan, dari sisi fisik kualitas SDM itu diketahui menurut tingkat kesehatan sedang dari sisi bukan fisik hal itu didasarkan pada tingkat pendidikan dan ketrampilan. Dalam kerangka luaran, dari sisi fisik maka kualitas SDM itu diketahui melalui angka kematian, usia harapan hidup, ukuran dan bentuk tubuh, kekuatan dan kesegaran tubuh, dan lain-lain. Sedang dari sisi bukan fisik, tingkat kepercayaan dan keimanan kepada Tuhan Yang Maha Esa, tingkat kesetiakawanan sosial, kemampuan hidup penduduk yang selaras dengan tuntutan lingkungan.

Dengan demikian, kita dapat mengetahui bahwa cara pengembangan sumber daya manusia (SDM) bisa dilakukan dengan berbagai cara. Antara lain,

${ }^{2}$ Wobiro Ati Wugtungam (1989), "Invesment in Human Resources and Economic Development: Some Thoughts for Papua New Guinea” dalam majalah Catalyst, Papua New Guinea, vol. 19, no. 3, hal. 239.

${ }^{3}$ Ibid.

${ }^{4}$ Ibid.

${ }^{5}$ Jimly Asshiddiqie, editor (1996), Sumber Daya Manusia untuk Masa Depan, (Jakarta: ICMI, PT Citra Putra Bangsa, dan Penerbit Mizan), hal. 107.

${ }^{6}$ Ibid., hal.108. 
ada tiga cara pengembangan SDM sebagai berikut: ${ }^{7}$ (1) pendidikan formal dan (2) lingkungan kerja dalam bentuk pelatihan sistimatik maupun latihan formal oleh perusahaan yang mempekerjakannya, program pendidikan bagi orang dewasa dan keikutsertaan dalam berbagai organisasi sosial, politik, budaya, dan agama. (3) pengembangan diri sendiri. atas dorongan diri sendiri, ada usaha untuk mendapatkan pengetahuan, ketrampilan, dan kapasitas yang lebih besar melalui kursus-kursus bacaan atau belajar dari orang lain. Atau dengan cara yang lebih sederhana, Human Resources dapat dikembangkan melalui pendidikan, perbaikan gizi makanan, pengurangan angka kelahiran, dan pengembangan ekonomi umum. ${ }^{8}$

Sebagaimana telah ditegaskan di atas, menurut Adam Smith manusia merupakan faktor yang esensial dalam pembangunan ekonomi bangsa. Pandangan ini tidak bisa diragukan lagi kebenarannya, terlepas siapa yang pertama kali mengutarakannya. Sehingga pengembangan sumber daya manusia dengan berbagai cara tersebut disebut human capital, yaitu investasi sumber daya manusia yang bertujuan meningkatkan produktivitas kerja dan penghasilan. ${ }^{9}$ Artinya investasi tidak hanya bisa dilakukan dalam bidang usaha sebagaimana yang sudah dikenal, tetapi investasi dapat dilakukan dalam bidang pengembangan sumber daya manusia, seperti melalui pendidikan dan pelatihan (training, workshop, seminar), migrasi, perbaikan gizi dan kesehatan. ${ }^{10}$ Jika prinsip investasi di bidang usaha dilakukan dengan mengurbankan konsumsi pada saat investasi dilakukan dengan tujuan untuk memperoleh tingkat konsumsi yang lebih tinggi beberapa waktu kemudian, maka investasi di bidang sumber daya manusia adalah mengurbankan sejumlah dana yang dikeluarkan dan kesempatan memperoleh penghasilan selama proses investasi untuk mendapatkan imbalan yang berupa tingkat penghasilan yang lebih tinggi untuk mencapai tingkat konsumsi yang lebih tinggi juga. ${ }^{11}$

Dengan demikian, dari sudut pandang faktor-faktor produksi, jelas manusia harus dimasukkan ke dalamnya sehingga menjadi bagian dari tenaga kerja. Sebagaimana kita tahu bahwa faktor-faktor produksi terdiri dari tanah, modal, tenaga kerja, dalam hal ini buruh punya tanggung jawab. ${ }^{12}$ Jadi sumber daya manusia juga merupakan modal. Adam Smith dalam the Wealth of Nations menyatakan hal itu, berikut ini:

"The improved dexterity of a workman may be considered in the same light as a

${ }^{7}$ Ibid.

${ }^{8}$ Wobiro Ati Wugtungam (1989), Invesment in Human Resources, hal. 241.

9 Payaman J. Simandjuntak (1982), Teori Sumber Daya Manusia dan Penerapannya dalam Prisma, vol. 11, no. 04, hal. 30.

${ }^{10}$ Ibid.

${ }^{11}$ Ibid.

${ }^{12}$ M. A. Mannan (1997), Teori dan Praktek Ekonomi Islam, (Yogyakarta: Dana Bhakti Prima Yasa), hal. 55, 58--62. 
machine or instrument of trade which fasilitates and abridges labour and which, though it costs a certain expence, repays that expence with a profit." 13

Terkait dengan ukuran keberhasilan investasi SDM yang berupa meningkatnya produktivitas kerja dan penghasilan, maka sebaliknya suatu produktivitas SDM dinyatakan rendah adalah berdasarkan tolak ukur yang berupa tindakan menganggur, bekerja kurang dari jam kerja yang wajar ( $35 \mathrm{jam} /$ minggu), dan pendapatan rendah. ${ }^{14}$ Lebih jauh, masalah kemiskinan, kebodohan, kesempatan kerja, serta lemahnya kesehatan merupakan problem produktivitas yang harus diselesaikan dalam skala prioritas. Karena hal itu menentukan keberhasilan atau kegagalan pembangunan dan pemberdayaan. ${ }^{15}$ Akan tetapi di sisi lain, pembangunan juga harus diukur berdasarkan nilai-nilai kemanusiaan seperti nilai kegotongroyongan dan kerjasama atau kemitraan.

Pada kenyataannya, kemiskinan merupakan problem yang semakin besar melanda bangsa Indonesia saat ini. Terkait dengan rendahnya SDM Indonesia, dari penelitian kita mengetahui bahwa telah terjadi kemiskinan di tengah kekayaan alam sendiri (kalimantan Timur). ${ }^{16}$ Keterbelakangan ekonomi itu semakin diperparah oleh terjadinya berbagai macam bencana yang datang secara bergelombang.

Sementara dari sebagian besar mereka yang miskin, mereka adalah orangorang Islam. Namun keprihatinan terhadap kelemahan ekonomis itu sedikit terobati dengan hadirnya lembaga keuangan Islam seperti Bank Syari' ah, Koperasi Syari'ah seperti BMT, Asuransi Syari'ah. Misalkan, kehadiran BMT yang telah menjamur di masyarakat menyatakan bidang garap mereka adalah pengusaha mikro atau pengusaha kecil-bawah yang jumlahnya lebih dari 32 juta yang sebagian besar adalah orang-orang Islam juga. ${ }^{17}$ Apakah kehadiran mereka cukup berarti dalam meningkatkan angka produktivitas atau mengurangi angka kemiskinan di kalangan orang-orang Islam? Pertanyaan ini sangat sulit diketahui jawabannya jika ketersediaan SDM ekonomi Islam yang unggul masih diragukan.

Pada intinya, kemiskinan adalah keadaan serba kekurangan yang diikuti oleh berbagai keadaan yang menekan kehidupan yang saling mempengaruhi

${ }^{13}$ Prijono Tjiptoheriyanto (1983), "Pengembangan Sumberdaya Manusia” dalam majalah Prisma, vol. 12, hal. 34. Lihat Adam Smith dalam the Wealth of Nations, 1776, Book II, chapter 1.

${ }^{14}$ Tadjuddin Noer Effendi (1993), Sumber Daya Manusia, Peluang Kerja, dan Kemiskinan, (Yogyakarta: Tiara Wacana), hal. 17.

${ }^{15}$ Soeroso Dasar (1986), Indonesia Sumber Daya Manusia Tahun 200, (Bandung: Angkasa), hal. 2.

${ }^{16}$ Mubyarto, penyunting (1997), Gerakan Nasional Penanggulangan Kemiskinan: Kajian Bersama Pengembangan Kebijaksanaan, (Yogayakarta: Aditya Media), hal. 135.

${ }^{17}$ Baihaqi Abd. Madjid (ed.). (2000), Paradigma Baru Ekonomi Kerakyatan Sistim Syariah: Perjalanan Gagasan dan Gerakan BMT, (Jakarta: PINBUK), hal. 186. 
dan menyejarah. ${ }^{18}$ Keadaan tersebut bukanlah keadaan yang dikehendaki oleh si miskin, melainkan sesuatu yang tidak bisa dihindari dengan kekuatan yang ada pada dirinya. Tidak terpenuhinya berbagai kebutuhan dan pelayanan dasar yang diperlukan oleh seseorang untuk hidup dan berkembang secara layak. ${ }^{19}$ Keadaan semacam itu disebut "kemiskinan struktural". Untuk itu, cara menanggulangi kemiskinan bisa berupa: ${ }^{20}$ (a) pengembangan kelembagaan (institutional building) (b) akses (c) kesejahteraan (welfare). (d) penyadaran (conscientization). (e) partisipasi politik (political participation).

\section{Ciri Etika Ekonomi Islam}

Dalam kehidupan ekonomi, Al-Qur'an menunjukkan banyak sekali tuntunan tatalaku agar manusia sukses di dunia dan akhirat secara seimbang, antara lain firman Allah dalam surat a-Qashshash: 77. ${ }^{21}$

Kebahagiaan dan keberuntungan di akhirat merupakan insentif moral, agar orang menciptakan kebaikan dan menghindari kerusakan dan agar orang memanfaatkan kesempatan yang diperoleh dalam kehidupan di dunia ini dengan sebaik-baiknya. ${ }^{22}$ Karena perhitungan dan kebahagiaan di akhirat ditentukan berdasarkan pada perbuatan di dunia. Nabi Muhammad Saw dan para sahabatnya juga mengajarkan dan memberi contoh yang nyata mengenai keseimbangan itu.

Abdel Hamid El-Ghazali memberikan penjelasan bahwa jika ekonomi menurut sistim kapitalisme dan sosialisme merupakan kenyataan yang bebas nilai atau keadaan yang netral, jelas hal itu karena mereka tidak mengakui nilai-nilai moral dan etika. ${ }^{23}$ Sebagai gantinya, mereka memusatkan kepentingan segala sesuatu daam kehidupan ekonomi menurut tolak ukur kebendaan semata. Sejarah mengajari kita bahwa setiap sistim yang diketahui manusia dipengaruhi oleh etika dan moralitas sedikit ataupun banyak. Meskipun demikian, dalam pemikiran

${ }^{18}$ Riza Prima Henda, dkk. (2003), Kemiskinan dan Kemandirian: Catatan Perjalanan dan Refleksi Bina Swadaya, (Jakarta: Yayasan Bina Swadaya), hal. 37.

${ }^{19}$ Ibid, hal. 38.

${ }^{20} \mathrm{Ibid}$, hal. 48.

${ }^{21}$ Yang artinya: $\bullet$ Carilah apa yang telah dianugerahkan Allah kepadamu untuk kehidupan di akhirat dan janganlah kamu lupakan bagianmu untuk kehidupan dunia dan berbuat baiklah sebagaimana Allah berbuat baik kepadamu dan janganlah kamu berbuat kerusakan di muka bumi. Sesungguhnya Allah tidak menyukai orang-orang yang berbuat kerusakan."

${ }^{22}$ M. Dawam Raharjo (1990), Etika Ekonomi dan Manajemen, (Yogyakarta: Tiara Wacana), hal. 29-30.

${ }^{23}$ Abdel Hamid El-Ghazali (1994), Man is The Basis of The Islamic Strategy for Economic Development, (Jeddah: Islamic Research and Training Institute Islamic Development Bank), hal. 13. 
ekonomi Barat baik kapitalis atau sosialis, nilai atau etika dipandang berada di luar konteks mekanisme sistim ekonomi. Sebaliknya, nilai atau etika merupakan pandangan pokok sistim ekonomi Islam atau Islam secara keseluruhan.

Jadi kita mempunyai ilmu ekonomi yang bernuansa agama atau agama yang mengajari ekonomi. Ilmu ekonomi Islam merupakan bagian terpadu dari jalan hidup yang utuh dan berdasarkan wahyu yang semuanya itu saling mempengaruhi secara seimbang. Sesungguhnya ilmu ekonomi Islam adalah pengetahuan untuk mencari kekayaan rizki yang telah ditentukan sebelumnya, sesuai dengan hukum wahyu. Atas dasar alasan inilah, ilmu ekonomi Islam dapat digambarkan sebagai ilmu ekonomi yang bernuansa keagamaan (religious Economics) dan ilmu ekonomi yang beretika (ethical economics). Sehingga dalam anggapan dasar analisisnya ilmu ekonomi Islam didasarkan pada pengertian manusia yang beretika (ethical man) dan tidak pada pengertian manusia ekonomi (economic mani) sebagaimana dalam kapitalisme atau prinsip manusia yang berkelompok (social cogwheel) dalam sosialisme. Oleh karena itu, ilmu ekonomi Islam didasarkan pada sendi-sendi etika yang jelas dengan memberikan perhatian lebih banyak kepada manusia yang beretika dan manusiawi. ${ }^{24}$

\section{Metode Pengembangan Ekonomi Konvensional}

Dalam sejarah ekonomi hingga kini, ada model Barat yang telah lama mengembangkan konsep perbaikan ekonomi tersebut. Model ini didasarkan pada ideologi dan sistem kapitalisme yang berpusat pada pangagungan nilai pribadi (individualisme). Karena itu, kebebasan pribadi diberikan seluas-luasnya dan paham kebendaan atau materialisme sangat diagungkan. Ciri model Barat adalah kebebasan dalam berusaha, motif keuntungan, kepemilikan pribadi, mekanisme pasar, dan mekanisme dan persaingan pemberian kredit. ${ }^{25}$

Gagasan dan pandangan humanisme tumbuh berkembang di luar zaman Renaissance dan Reformation. "Humanisme" memperkuat masalah pribadi dan proses penciptaan kekayaan demi perlindungan kebebasan dan hak-hak asasi manusia dan mendukung "libertanisme", penelitian ilmiah dan eksplorasi. Kecenderungan baru ini memberikan sumbangsih yang berupa sejumlah perubahan baik dalam sikap maupun tindakan yang menyebabkan perkembangan kapitalisme dan hak-hak asasi manusia. Proses penciptaan kekayaan demi dirinya sendiri sangat dimuliakan dan diarahkan untuk pengumpulan modal kapitalis. Kegiatan ilmiah mengarah pada penemuan tehnis dan mekanis. Eksplorasi mengarah pada penemuan kawasan baru yang digabung dengan misi perolehan kekayaan. Lahirnya revolusi industri memacu proses perkembangan. Penjajahan memerankan peranan dalam proses tersebut dengan cara memperbudak bangsa

\footnotetext{
${ }^{24}$ Ibid, hal. 13.

${ }^{25} \mathrm{Ibid}$, hal. 31.
} 
yang lemah dan memeras ekonomi mereka. Perkembangan intelektual yang tumbuh di Barat selama masa Renaissance dan Reformation dapat ditelusuri berasal dari pengaruh peradaban Islam, manifest zaman Reformation secara umum dan ajaran Protestan secara khusus yang menyebabkan egalitarianisme dan kebebasan pribadi.

Meskipun demikian, perkembangan diikuti dengan perampasan atau eksploitasi di samping pendapatan banyak materi yang menjadi ciri model ini. Dan ketidakadilan kembali muncul sebagai hasil kapitalisme kelas yang mendasar, materialismenya yang nyata, tidak adanya perlindungan yang melawan monopolisme yang memang membuka jalan pada tindakan mopolistik.

Dengan tekanan eksploitasi, kebebasan (freedom) terancam. Hal ini memuncak pada depresi yang luar biasa yang melumpuhkan dunia pada akhir tahun 1920 yang berlangsung hingga 1930. Segala usaha telah dilakukan untuk merubah model tersebut secara teoritis dan memperbaiki penerapannya. Keynes dalam ilmu yang dikembangkannya berpandangan bahwa pandangan teoritis mengenai negara yang bertugas sebagai penjaga dan keseimbangan otomatis tidak layak lagi. Dia berpendapat bahwa negara seharusnya ikut mencampuri kegiatan ekonomi supaya meningkatkan permintaan kenyataan (real demand) terhadap konsumsi dan investasi sehingga pekerjaan sepenuhnya dapat disediakan.

Oleh karena itu, kapitalisme memandang manusia sebagai Rasional Economic Man. Hal itu pandangan Darwinisme-sosial. Menurut pandangan tersebut, utilitarianme (asas manfaat) dan materialistis yang cirinya memuaskan kepentingan pribadi dan meraih kekayaan sebesar-besarnya dan pemuasan keinginan. ${ }^{26}$

\section{Islam dan Sumber Daya Manusia (SDM)}

Islam sebagai agama dan sistim kehidupan dalam hal ini kembali harus menyelamatkan kemanusiaan dari kebodohan, korupsi, penderitaan, ketidakadilan, dan kesengsaraan. ${ }^{27}$ Islam menyediakan penyelesaian yang sempurna melalui sistim keyakinannya yang mewadahi semua seperti etika, penyerahan diri kepada Tuhan, transaksi duniawi untuk pemurnian kemanusiaan dalam kehidupan dunia dan melalui perbuatan manusia itu sendiri. Hal ini dapat diejawantahkan dengan cara mengikis ketidakadilan dan pelurusan penyimpangan melalui pendidikan, kendali orang banyak (sosial), dan aturan yang mengatur aspek-aspek kehidupan. Tujuan puncak dalam Islam adalah ketundukan manusia atas semua segala sesuatu yang diciptakan dengan cara mengetahui tempatnya di dalam jagad raya, pengetahuan dan alasan penciptaan dirinya sekalipun telah

${ }^{26}$ M. Umer Chapra (2001), The Future of Economics: an Islamic Perspective, penerj. Amdar Amir (dkk), (Jakarta: SEBI), hal. 66.

${ }^{27}$ Ibid., hal. 41 
mendapatkan kemuliaan dirinya yang dianugerahkan Allah Swt. ${ }^{28}$

Menurut Muhammad Iqbal, Islam mengikuti prinsip gerakan. ${ }^{29}$ Dengan prinsip ini, Islam menolak pandangan yang statis dan mengikuti pola hidup yang dinamis. Senada dengan pandangan Iqbal, Thahir Abdul Muhsin Sulaiman menegaskan bahwa prinsip kemajuan dalam Islam adalah bekerja. ${ }^{30}$ Karena dalam Islam kemiskinan sebenarnya dianggap sebagai penyakit masyarakat. ${ }^{31}$ Karena dalam Islam kemiskinan sebenarnya dianggap sebagai penyakit masyarakat. ${ }^{32}$

Salah satu tujuan dari usaha dan tindakan manusia adalah mencapai falah. ${ }^{33}$ Falah adalah selamat, bahagia, sukses (berhasil atau jaya), bernasib baik, makmur. Falah juga berarti orang yang mempersiapkan lahan dan segala kondisi yang dibutuhkan untuk berkembangnya benih, sehingga karena kondisi tanah dan air yang mendukung maka benih itu menjadi tanah yang luas yang sangat menguntungkan. Jika manusia menyiapkan kondisi yang membantu dirinya untuk menjadi manusia yang layak di setiap aspek dan dimensi eksistensinya, maka dia akan terbebaskan dari egoisme dan hawa nafsu yang membelenggu dirinya. Kerja merupakan kunci untuk memanfaatkan sumber daya alam. ${ }^{34}$ Pada dasarnya, tak ada kerja berarti tak ada pendapatan. ${ }^{35}$ Dalam Islam, orang yang bekerja keras mencari nafkah adalah setara dengan orang yang berjuang di jalan Allah bertujuan untuk memperkuat basis integritas dan moralitas manusia dan memasyarakatkan keadilan sosial. Akan tetapi malas-malasan dan menganggur merupakan tindakan dan keadaan yang dibenci oleh Allah.

28 "Maka hadapkanlah dengan lurus mukamu kepada agama Islam, fitrah (ciptaan) Allah Tuhan yang telah menciptakan manusia kepada agama itu. tidak ada perubahan pada ciptaan Allah. Itulah agama yang lurus. Tetapi kebanyakan manusia tidak mengetahui." QS. Ar-Rum: 30. Allah Swt juga berfirman: "Dan sesungguhnya telah kami muliakan anak-anak Adam, kami angkut mereka di daratan dan di lautan, kami beri mereka rizki dari yang baik-baik dan kemi lebihkan mereka dengan kelebihan yang sempurna atas kebanyakan sesuatu yang telah kami ciptakan.” QS. Al-Isra': 70.

${ }^{29}$ Muhammad Iqbal (1966), The Reconstruction of Religious Thought in Islam, penerj. Ali Audah, Taufik Ismail, dan Goenawan Muhammad, (Jakarta: Tintamas), hal. 143.

30 Thahir Abdul Muhsin Sulaiman (1985), Menanggulangi Krisis Ekonomi Secara Islam, (Bandung: al-Ma'arif), hal. 145. Lihat QS. At-Taubah: 105.

${ }^{31}$ Musthafa Husni Assiba’i (1981), Kehidupan Sosial menurut Islam: Tuntunan Hidup Bermasyarakat, penerj. M. Abdai Ratomy, (Bandung: Diponegoro), hal. 155. Lihat QS. Hud: 6 dan 67 serta QS. Al-Mulk: 15.

${ }^{32}$ Musthafa Husni Assiba’i (1981), Kehidupan Sosial menurut Islam: Tuntunan Hidup Bermasyarakat, penerj. M. Abdai Ratomy, (Bandung: Diponegoro), hal. 155. Lihat QS. Hud: 6 dan 67 serta QS. Al-Mulk: 15.

${ }^{33}$ Muhammad Husaini Bahesty (2003), Intisari Islam: Kajian Komprehensiftentang Hikmah Ajaran Islam, penerj. Ilyas Hasan, (Jakarta: Lentera), hal. 178.

${ }^{34}$ Ibid, hal 397.

35 Ibid, hal 399. 
Orang mukmin kuat lebih disukai oleh Allah. ${ }^{36}$ Ibnu Taimiyah menyebutkan Usman bin 'Affan, 'Ali bin Abi Thalib, 'Abdurrahman bin 'Auf adalah orang-orang mukmin yang kuat. ${ }^{37}$ Orang yang beriman kepada Allah adalah orang yang aktif dalam hidup di dunia ini. ${ }^{38}$ Etos yang dominan dalam Islam adalah menggarap kehidupan ini secara giat, dengan mengarahkannya kepada yang lebih baik (ishlab). Namun Yusul al-Qardhawi mengingatkan bahwa dalam Islam sosok individu yang dikehendaki Allah Swt setelah menjadi kaya atau kuat dalam beberapa segi kehidupannya adalah yang dermawan dan murah hati. ${ }^{39}$

\section{Manusia Sewajarnya}

Metode Islam berpusat kepada manusia yang sewajarnya yang memiliki kelemahan sekaligus kelebihannya. Prinsip ini tidak sebagaimana gambaran teoritis ekonomi konvensional yang memandang bahwa manusia adalah makhluk ekonomis (an economic being), manusia ekonomi (economic man), atau makhluk kebendaan (material being)..$^{40}$ Dia adalah manusia yang terikat dengan etika Islam yang merupakan sumber perbuatan dan sistim ilmu ekonomi Islam yang menjadi kelanjutan dari keyakinan-keyakinan keagamaan. Dia adalah manusia sewajarnya yang memiliki integritas, kesopanan, dan moralitas. Di sini perlu ditegaskan bahwa etika Islam sebenarnya merupakan etika universal. Sehingga dia tidak ekslusif berlaku bagi umat Islam. hanya saja dikatakan demikian karena hal itu diambil berdasarkan pada pemahaman dan perenungan atas sumbersumber Islam.

Gambaran tentang manusia sewajarnya adalah gambaran nyata tentang manusia, yang terbebas dari perbudakan, pemerasan, ketidakadilan, dan penindasan dalam semua bentuknya yang bermacam-macam.. Dia adalah manusia yang memiliki kewibawaan dan harga diri yang menikmati kemerdekaan dan keadilan. Tanpa dua nilai tersebut, bumi tidak akan pernah sama sekali dijadikan

${ }^{36}$ Nurcholis Madjid (1992), Islam Doktrin dan Peradaban, (Jakarta: Paramadina), hal. 418-422.

${ }^{37}$ Ibid, hal. 419.

${ }^{38}$ Ibid, hal. 420

${ }^{39}$ Muhammad Yusuf al-Qardhawi (1996), Konsepsi dalam Mengentaskan Kemiskinan, penerj. Umar Fanany, Surabaya: Bina Ilmu, hal. 217. Hal itu berdasarkan pada QS. Al-Baqarah: 245, 261-262, 274, Ali Imran: 133-134, As-Saba': 39, al-Hadid: 7, al-Hasyr: 9, al-Munafiqun: 10, al-Muzammil: 20, dan al-Insan: 8-10. Juga keterangan itu banyak terdapat di dalam sunnah Rasul Saw antara lain dari HR Ahamad, Ibnu Huzaimah, Ibnu Hibban, dan al-Hakim yang berbunyi:

$$
\text { قال رسول الله س م : كل امرء فى ظل صدقته حتى يقضى بين الناس. }
$$

Artinya: "Rasulullah Saw bersabda: setiap orang berada dalam naungan shadaqahnya sehingga dia memberikannya kepada orang banyak."

${ }^{40}$ Abdel Hamid El-Ghazali (1994), Man is The Basis, hal. 42. 
beradab oleh manusia. Kemunduran dan keterbelakangan akan berlangsung lambat-laun atau dalam waktu cepat, sehingga ujian akan terus mendera kualitas diri manusia.

\section{Matapencaharian dan Kehidupan}

Allah telah menyediakan makanan untuk manusia agar manusia terlindungi dari bahaya kelaparan dan tepat berlindung dari ketakutan, untuk mengamankan matapencaharian sebagai bekal untuk memperbaiki dunia atas dasar pengetahuan Allah dengan seluruh keagungan zat, sifat, dan namanya, sehingga manusia memperoleh kebebasan yang dikaruniakan kepadanya Allah-lah yang memberi manusia makanan dan matapencahariannya dan Dia-lah yang menentukan masa hidupnya. ${ }^{41}$

\section{Mencari Matapencaharian}

Di dalam Al-Qur'an, perjalanan untuk mencari matapencaharian telah dihubungkan dengan kesejahteraan kebendaan dan jiwa serta disamakan dengan perang demi Allah karena merupakan tindakan untuk memenuhi tugas suci untuk mengembangkan kehidupan di bumi. ${ }^{42}$ Rasululloh Saw menegaskan hal tersebut dalam sabdanya: "Barangsiapa yang berusaha membantu janda atau

${ }^{41}$ Allah Swt berfirman: •Dan di langit terdapat rizkimu dan terdapat pula apa yang dijanjikan kepadamu. Maka demi Pemelihara langit dan bumi sesunggguhnya Dia yang dijanjikan kepadamu itu sungguh nyata kebenarannya seperti apa yang kamu ucapkan dengan sungguh-sungguh.” QS. Adz-Dzariyyat: 22-23. Allah berfirman dalam ayat yang lain:

"Sesuatu yang bernyawa tidak akan meninggal dunia melainkan dengan izin Allah sebagai ketetapan yang telah ditentukan waktunya. Barangsiapa menghendaki pahala dunia, niscaya akan Kami berikan itu kepadanya dan barangsiapa menghendaki pahala akhirat, niscaya akan kami berikan itu kepadanya dan kami akan memberikan balasan kepada orang-orang yang berterimakasih (bersyukur).” QS. Ali Imran, 145.

${ }^{42}$ QS. Al-Jum'ah: 10. Yang artinya: •Maka apabila telah ditunaikan sembahyang, maka bertebaranlah kalian di muka bumi dan carilah karunia Allah dan banyak ingatlah kepada Allah supaya kamu beruntung." Hal itu diperkuat Allah dalam firmanNya yang lain, QS. Al-Muzammil: 20: • •Dia mengetahui akan ada di antara kalian yang sakit dan yang lainnya mengadakan perjalanan di muka bumi untuk mencari kelebihan yang diberikan Allah dan yang lainnya lagi berperang di jalan Allah, maka bacalah apa yang mudah dari Al-Qur'an dn dirikanlah sembahyang tunaikanlah zakat dan berikanlah pinjaman kepada Allah pinjaman yang baik. Dan kebaikan apa saja yang kamu perbuat untuk dirimu niscaya kamu memperoleh balasannya di sisi Allah sebagai balasan yang paling baik dan paling besar pahalanya dan mohon ampunlah kepada Allah sesungguhnya Allah Maha Pengampun lagi Maha Penyayang.“ 
orang miskin, maka dia seperti tentara Allah." ${ }^{43}$ Dan dalam hadis yang lain. dia bersabda: "Barangsiapa berusaha membantu janda atau orang miskin, maka dia seperti tentara Allah, berpuasa siang harinya dan beribadah pada malam harinya." ${ }^{44}$ Jadi berperang karena Allah dalam arti yang sesungguhnya adalah tugas beberapa orang Muslim tertentu dan tidak oleh semua orang Muslim. Jika tidak ada keadaan itu, maka semua orang Muslim harus mengemban tugas mengembangkan atau menyejahterakan bumi.

Usaha mendapatkan matapencaharian untuk mencapai salah satu kualitas kehidupan yang terbaik dijalankan melalui kerja yang jujur dan yang baik, sesuai dengan kehendak Allah dan ketundukan kepadaNya. ${ }^{45}$ Terkait dengan hal itu, Nabi Saw menyatakan: "tidak ada orang yang memakan sesuatu yang lebih baik daripada apa yang dia peroleh dari kerja tangannya sendiri. Nabi Dawud As makan dari apa yang telah dikerjakan oleh tangannya sendiri. ${ }^{46}$

\section{Metode Peningkatan Sumber Daya Manusia dalam Perspektif Ekonomi Islam}

Al-Qur'an merupakan sumber ajaran Islam yang tertinggi yang berisi antara lain ajaran tatalaku atau akhlak atau etika yang sangat penting artinya dalam kehidupan. Ajaran tatalaku dalam Islam sangat sejalan dengan pandangan Islam tentang manusia bahwa manusia adalah ciptaan Allah yang berdimensi banyak yang memiliki raga-biologis, hati, jiwa dan akal. Sehingga kebutuhan diri manusia juga banyak meliputi kebutuhan kebendaan, kebutuhan jiwa, kebutuhan berketuhanan, kebutuhan sosial, dan kebutuhan berperadaban; manusia adalah ciptaan Allah yang individual sekaligus sosial; manusia akan menjalani hidup yang jauh lebih lama dan merupakan kehidupan sejati setelah dia mati. Terkait dengan ajaran Islam tentang etika, manusia merupakan sorotan satu-satunya. Karena menurut paradigma Al-Qur'an, manusia adalah makhluk beretika. Artinya dia membutuhkan tatalaku yang mengatur persoalan baik dan buruk demi kebahagiaan hidupnya. Karena di dalam diri manusia ada potensi

\footnotetext{
${ }^{43}$ Muslim (t.th.), Shahih Muslim, (Beirut: Dar Ihya' at-Turats al-'Arabi). Muhaqqiq: Muhammad Fu'ad 'Abd al-Baqi, juz IV, hal. 2286.

${ }^{44}$ Ibid.

${ }^{45}$ Abdel Hamid El-Ghazali (1994), Man is The Basis, hal. 45. Dalam hal ini, Allah Swt berfirman, QS. An-Nahl: 97: "Barangsiapa yang mengerjakan perbuatan yang baik laki-laki maupun perempuan dalam keadaan beriman, maka sesungguhnya akan kami berikan kepadanya kehidupan yang baik dan sesungguhnya akan kami beri balasan kepada mereka dengan pahala yang lebih baik dai apa yang telah mereka kerjakan.”

${ }^{46}$ Al-Bukhari (1987), Shahih al-Bukhari, (Beirut: Dar Ibnu Katsir al-Yamamah). Muhaqqiq: Mushthafa Daib al-Bagha, juz 3, hlm. 1256.
} 
kebaikan dan keburukan. ${ }^{47}$

Tujuan metode Islam tentang perkembangan atau perbaikan hidup adalah untuk mengembalikan manusia pada ciri aslinya yang bersifat ilahiah dengan kembali pada prioritas pertamanya: prioritas pertama perkembangan itu adalah kesejahteraan manusia itu sendiri.

Tidak seperti metodologi perbaikan hidup yang dibuat oleh manusia, Islam telah menunjukkan siapa yang memerankan proses perbaikan hidup manusia itu, yaitu manusia itu sendiri. Senyatanya, perbaikan hidup harus dimulai oleh manusia. Atas peran dan jerih payah manusia, baru perbaikan hidupnya bisa maju setahap demi setahap. Menurut metodologi yang berasal dari wahyu ini, tempat manusia di dunia ini bersifat transendental. Manusialah kekuatan yang mengendalikan proses perbaikan hidup. ${ }^{48}$

Pada saat yang sama, manusia juga merupakan alasan keberadaan (raison d'etre) dan pengambil untung dari perbaikan hidup itu. Melalui perbaikan hidup manusia, manusia akan memenuhi kewajibannya untuk menyembah yang bisa dilaksanakan melalui setiap aspek peradabannya.yang merupakan buah dari proses tersebut sebagaimana yang ditetapkan Allah Swt. Oleh karena itu, perbaikan hidup merupakan proses yang berkelanjutan yang menjaga keberlanjutan itu dari keberkanjutan penyembahan manusia kepada Tuhannya. ${ }^{49}$

Nabi Muhammad Saw telah memberikan tuntunan untuk mengentaskan kemiskinan di Mekah dan Madinah..$^{50}$ Pendukung Nabi Saw yang kaya dalam mengatasio kelemahan itu adalah Khadijah (istri Nabi Saw) sendiri. Dari kelompok Muhajirin, mereka adalah 'Abdurrahman bin 'Auf, Usman bin 'Affan, 'Umar bin al-Khaththab, Talhah bin Ubaidillah, Zubair bin 'Awwam, dan Sa'ad bin Abi Waqqas Zuhri. Dari kelompok Anshar, mereka adalah Sa'ad bin Ubadah dan anaknya Qais, Sa'ad bin Mu'ad Sa'd bin ar-Rabi', Qatadah bin an-Nu'man, Abu Ayyub, dan lain-lain. Sementara yang miskin seperti Bilal, Zaid, dan Abu Hurairah. Untuk mengentaskan kemiskinan ini, Nabi Saw menggunakan tiga metode, (1) metode penanaman sikap sukarela (the voluntary method) terhadap

${ }^{47}$ Allah Swt berfirman: Dan kepada Tsamud ada saudara mereka Shalih. Dia berkata, "hai kaumku sembahlah Allah kalian tidak punya Tuhan selain Dia. Dia telah menciptakan kamu dari tanah dan menyejahterakan kamu di dalamnya sehingga mohonlah ampunan kepadaNya kemudian kembalilah kepadanya. Sesungguhnya Tuhanku dekat lagi menanggapi permohonan." QS. Asy-Syamsy: 7 dan 8.

${ }^{48}$ QS. Hud: 61.

${ }^{49}$ Dan tidak aku ciptakan jin dan manusia kecuali agar mereka menyembahku. “ QS. Adz-Dzariyat: 56-58. Allah Swt berfirman pada ayat yang lain: "ucapkanlah sesungguhnya shalatku, ibadahku, hidup dan matiku hanyalah untuk Alah semata, pemelihara jagad raya. QS. AI-An’am : 162-163.

${ }^{50}$ Sule Ahmed Gusan (1993), "The Prophet Muhammad and the Problem of Poverty and Distress" dalam jurnal Hamdard Islamicus, (Pakistan: Bait al-Hikmat), vol. 16, no. 1, hal. 19. 
semua kejadian yang dialami, seperti dengan konsep ujian dalam hidup. Agar lulus ujian, Nabi Saw mengajari orang miskin mengenai pentingnya kerja dan keburukan tindakan meminta-minta dan melihat kepada orang yang jauh lebih terpuruk daripada dirinya sehingga mereka tidak putus asa. Menghimbau agar menerima dengan sukarela pemberianNya yang sudah ada dan tetap berusaha mendapatkan kumurahan hatiNya yang belum menjadi kenyataan, dengan konsep kekhalifahan dan amanah. ${ }^{51}$ Nabi Saw mengajari mengenai sikap terhadap dunia agar manusia hidup seolah-olah akan hidup selamanya dengan menimbulkan kesejahteraan bagi manusia di sekitar dirinya dan keturunannya di masa depan. Terhadap kehidupan akhirat, manusia semestinya bersikap agar hidup seolaholah akan mati besuk sehingga dia harus mempersiapkan dirinya menghadap Allah Swt untuk mendapatkan surga $\mathrm{Nya}^{52}$, dengan konsep persaudaraan dan keakraban Islam yang secara mudah buktinya dapat ditemukan dalam tindakan nabi mempersaudarakan antara kaum muhajir dan anshar pada awal mereka bertemu. ${ }^{53}$ Serta membimbing orang-orang yang kaya supaya membantu yang miskin. Karena kekayaan dan kemiskinan keduanya dapat menimbulkan kejahatan bagi manusia. (2) metode pelaksanaan kewajiban (the compulsory method), seperti dengan ajaran kewajiban memperkuat keluarga ${ }^{54}$, menyantuni sanak keluarga yang dekat ${ }^{55}$, membayar zakat. ${ }^{56}$ (3) metode pertanggungjawaban negara (the Method of the State's Responsibility).

\footnotetext{
${ }^{51}$ Ibid, hal. 20.

52 Ibid, hal. 21.

${ }^{53}$ Ibid, hal. 24.

${ }^{54}$ Ibid, hal. 24.

55 Ibid, hal. 25.

56 Ibid, hal 26.
} 


\section{X. 'Abdurrahman bin 'Auf: Contoh SDM Muslim Sukses di Dunia dan Akhirat}

'Abdurrahman bin 'Auf (w.31 H/652M) adalah satu dari sepuluh sahabat besar Nabi Muhammad Saw yang dijanjikan akan masuk surga (al-asyarah almubasysyarah = sepuluh orang yang digembirakan). ${ }^{57}$ Dia memiliki watak maju atau dinamis dan progresif. Watak ini terlihat sangat jelas ketika kaum muslimin hijrah ke Madinah. Telah menjadi kebiasaan Rasululloh Saw pada waktu baru hijrah ketika itu untuk mempersaudarakan dua orang sahabat antara seorang muhajirin dan seorang anshor. Orang-orang anshor membagi seluruh kekayaan mereka menjadi dua bagian dengan orang-orang muhajirin, hingga pada persoalan rumah tangga seperti istri. Apabila dia beristri dua, satu orang diceraikannya untuk diperistri saudaranya.

Ketika itu, Rasululloh Saw mempersaudarakan 'Abdurrahman bin 'Auf dengan Sa'ad bin Robi. Cerita ini dituturkan oleh Anas bin Malik:

“...dan berkatalah Sa'ad kepada 'Abdurrahman bin 'Auf, saudaraku, aku adalah penduduk Madinah yang kaya raya, silahkan pilih separuh hartaku dan ambillah! Dan aku mempunyai dua orang istri, coba perhatikan yang lebih menarik perhatian saudara, akan kuceraikan dia sehingga saudara dapat memperistrinya." Jawab 'Abdurrahman, semoga Allah memberkati saudara, istri dan harta saudara! Tunjukkanlah letak pasar agar aku dapat berniaga...!' 'Abdurrahman kemudian pergi ke pasar dan berjual beli di sana; dia pun memperoleh keuntungan.

Kehidupan 'Abdurrahman bin 'Auf di Madinah, baik semasa Rasululloh Saw maupun sesudahnya, terus meningkat. Barang apa saja yang dipegangnya dan dijadikannya modal perdagangan pasti menguntungkannya. Dia mampu menguasai resiko yang dihadapinya. Seluruh usahanya ditujukan untuk mencapai rida Alah Swt semata, sebagai bekal di alam terakhir (akhirat) kelak.

Suatu hari, dia menjual tanah seharga 40 ribu dinar, kemudian semua uang itu dibagi-bagikannya kepada keluarganya dari Bani Zuhroh, istri Nabi

${ }^{57}$ Dia berasal dari Bani Zuhrah dari suku Quraisy. Dia masuk Islam pada permulaan dakwah Nabi Saw, yakni sebelum Nabi Saw memasuki Daral-Arqam dan menjadikannya sebagai tempat pertemuan dengan para sahabatnya, sesama mukmin. Dia termasuk delapan sahabat yang mula-mula masuk Islam. Abu Bakar-lah yang pertama kali datang kepadanya untuk menyampaikan Islam dan berhasil mengajaknya masuk Islam. Semenjak masuk Islam sampai meninggalnya pada usia 75 tahun, dia menjadi teladan yang cemerlang sebagai orang mukmin besar. Abu Bakar mengangkatnya menjadi anggota kelompok musyawarah yang berjumlah enam orang sebagai calon khalifah yang akan dipilih menjadi penggantinya, seraya berkata:"Rasululloh Saw meninggal dunia dalam keadaan rida kepada mereka." Ketika Nabi Saw memerintahkan para sahabatnya hijrah ke Mekkah, 'Abdurrahman bin 'Auf ikut hijrah, kemudian kembali lagi ke Mekkah. Dia juga ikut hijrah untuk kedua kalinya ke Habsyah dan kemudian ke Madinah. Dia ikut bertempur di perang Badar, Uhud, dan peperangan lainnya. Dewan Redaksi Ensiklopedi Islam. (1997). Ensiklopedi Islam. Jakarta: Ichtiar Baru Van Hoeve, hal. 24 dan 25. 
Saw dan kaum fakir miskin. Pada hari lain, dia menyerahkan 1500 ekor kuda untuk perlengkapan pasukan Islam. Menjelang wafatnya, dia mewasiatkan 50 ribu dinar untuk jalan Allah Swt, dan 400 dinar untuk setiap orang yang ikut perang Badar dan masih hidup.

Tentu saja kepribadian wiraswasta dan kemandirian 'Abdurrahman bin 'Auf baru terbentuk setelah melalui banyak proses pengalaman dan kemampuan memahami konsep Islam yang diajarkan Nabi Saw. Setidaknya kita tahu bahwa dia tidak lebih menonjol daripada Abu Bakar dalam kegiatan perdagangan di Mekkah sebelum hijrah itu. Dia termasuk orang yang berkembang dengan pengalaman dan pengetahuan keislaman yang luas. Kemudian 'Abdurrahman bin 'Auf adalah sahabat Nabi yang berhasil maju pesat dalam perdagangan tetapi sangat dermawan dan bermurah hati. Dia menyalurkan harta kekayaannya untuk disumbangkan kepada kalangan yang membutuhkan dan keperluan kebaikan yang selaras dengan ajaran Islam.

Dari penjelasan di atas, 'Abdurrahman bin 'Auf adalah sosok pengusaha Muslim yang dalam kesuksesannya tetap menjaga etos kerja yang tinggi dan efektif, hidup hemat namun dermawan, kejujuran dan keberanian berspekulasi, dan memegang teguh keimanan yang semuanya diterapkan dalam tindakan dan sikap hingga akhir hayatnya. Sehingga pengalaman dan pengetahuannya tidak lagi terjadi sebatas perkataan dan pernyataan. Dia juga mempunyai wawasan luas tentang sikap pengelolaan harta yang dituntunkan Islam; sikap kemandirian dan ketekunan serta kemampuan menghadapi resiko sehingga apa saja yang disentuhnya dapat menguntungkannya.

\section{Penutup}

Pandangan Islam tentang harta sangat penting untuk diketahui sehingga muncul sikap optimis dalam memberdayakan diri secara ekonomis dan spiritual sekaligus. Karena kegiatan meraih rizki dapat bernilai ibadah dan menjadi kegiatan yang diridai Allah. Terlebih hal itu digunakan untuk kegiatan-kegiatan kebaikan yang sesuai dengan tugas kekhalifahan manusia. Untuk itulah, sebagai khalifah manusia Muslim tidak boleh lemah, secara perorangan maupun kelembagaan. Jadi paradigma Islam yang memihak pada kemajuan di atas akan benar-benar menghasilkan kemajuan dan pemberdayaan, jika Sumber Daya Manusia (SDM) yang ada mampu memahami dan melaksanakannya dalam realitas sosial.

\section{DAFTAR PUSTAKA}

Asshiddiqie, Jimly, ed. (1996). Sumber Daya Manusia untuk Masa Depan. Jakarta: ICMI, PT Citra Putra Bangsa, dan Penerbit Mizan.

Assiba'i, Musthafa Husni (1981). Kehidupan Sosial menurut Islam: Tuntunan Hidup Bermasyarakat. penerj. M. Abdai Ratomy. Bandung: Diponegoro. 
Bahesty, Muhammad Husaini (2003). Intisari Islam: Kajian Komprehensiftentang Hikmah Ajaran Islam. penerj. Ilyas Hasan. Jakarta: Lentera.

Baird, Lloyds (1992). Managing Human Resources: Integrating People and Business Strategy. Illinois: Business One Irwin.

Bukhari, Al- (1987). Shahih al-Bukhari. Dar Ibnu Katsir al-Yamamah. Muhaqqiq: Mushthafa Daib al-Bagha.

Chapra, M. Umer (2001). The Future of Economics: an Islamic Perspective. penerj. Amdar Amir (dkk). Jakarta: SEBI.

Dasar, Soeroso (1986). Indonesia Sumber Daya Manusia Tahun 200. Bandung: Angkasa.

Dewan Redaksi Ensiklopedi Islam (1997). Ensiklopedi Islam. Jakarta: Ichtiar Baru Van Hoeve.

Effendi, Tadjuddin Noer (1993). Sumber Daya Manusia, Peluang Kerja, dan Kemiskinan. Yogyakarta: Tiara Wacana.

Ghazali, Abdel Hamid El- (1994). Man is The Basis of The Islamic Strategy for Economic Development. Jeddah: Islamic Research and Training Institute Islamic Development Bank.

Gomes, Faustino Cardoso (1995). Manajemen Sumber Daya Manusia. Yogyakarta: Andi Offset.

Gusan, Sule Ahmed (1993). "The Prophet Muhammad and the Problem of Poverty and Distress" dalam jurnal Hamdard Islamicus. Pakistan: Bait alHikmat.

Henda, Riza Prima, dkk. (2003). Kemiskinan dan Kemandirian: Catatan Perjalanan dan Refleksi Bina Swadaya. Jakarta: Yayasan Bina Swadaya.

Iqbal, Muhammad (1966). The Reconstruction of Religious Thought in Islam. penerj. Ali Audah, Taufik Ismail, dan Goenawan Muhammad. Jakarta: Tintamas.

Madjid, Baihaqi Abd. ed. (2000). Paradigma Baru Ekonomi Kerakyatan Sistim Syariah: Perjalanan Gagasan dan Gerakan BMT. Jakarta: PINBUK.

Madjid, Nurcholis (1992). Islam Doktrin dan Peradaban. Jakarta: Paramadina.

Mannan, M. A. (1997). Teori dan Praktek Ekonomi Islam. Yogyakarta: Dana Bhakti Prima Yasa.

Mondy, R Wayne, et al. (1993). Human Resources Management. Boston: Allyn\&Bacon.

Mubyarto, penyunting (1997). Gerakan Nasional Penanggulangan Kemiskinan: Kajian Bersama Pengembangan Kebijaksanaan. Yogayakarta: Aditya Media.

Muslim (t.th.). Shahih Muslim. Beirut: Dar Ihya' at-Turats al-'Arabi. Muhaqqiq: Muhammad Fu'ad 'Abd al-Baqi.

Purba, Sri Diba (2000). Pengaruh Kualitas SDM terhadap Pendapatan di DIY. Yogyakarta: UGM.

Qardhawi, Muhammad Yusuf al- (1996). Konsepsi dalam Mengentaskan Kemiskinan. penerj. Umar Fanany, Surabaya: Bina Ilmu. 
Syafrudin Arif M. M.: Need AssesmentSDM ...

Qur'an al-Karim, Al-.

Raharjo, M. Dawam (1990). Etika Ekonomi dan Manajemen. Yogyakarta: Tiara Wacana.

Saefuddin, A. M., et all (1990). Islam untuk Disiplin Manajemen. Jakarta: Departemen Agama.

Simandjuntak, Payaman J. (1982). "Teori Sumber Daya Manusia dan Penerapannya" dalam Prisma.

Singer, Marc G. (1990). Human Resources Management. Boston: PWS-Kent Pub.

Sulaiman, Thahir Abdul Muhsin (1985). Menangguklangi Krisis Ekonomi Secara Islam. Bandung: al-Ma'arif.

Tjiptoheriyanto, Prijono (1983). "Pengembangan Sumberdaya Manusia" dalam majalah Prisma.

Wugtungam, Wobiro Ati (1989). "Invesment in Human Resources and Economic Development: Some Thoughts for Papua New Guinea" dalam majalah Catalyst. Papua New Guinea. 